\section{Chief thieves}

Don't you trust me? I'm the chief thief," says the man who had been sought out by my Canadian friend in Ghana West Africa. She had lost the stereo, computer and printer from her home office. Each town has a chief thief. "Retired" from the business, his job is to see to the division of spoils. If asked to intervene, he decides whether to extend his protection to the victim or the perpetrator of the crime.

$\mathrm{W}$

e, the affluent, have become the chief thieves. We decide who we will protect with the global economic system; we work and worry to find a trillion dollars to bail out Wall Street gamblers, but are unable to raise the $\$ 200$ billion needed by 2015 to meet the Millennium Development Goals of reducing poverty, maternal and child death rates, improving the status of women and limiting infectious diseases including AIDS.

What kind of thieves are we? We steal money. A collusion of wealthy people in poor and rich countries now has the net flow of capital moving from the developing world to ours. ${ }^{1}$ We buy goods for less than they cost to produce and our overconsumption adds to the pollution and environmental degradation in the Third World. We steal trained people. The paltry wages paid to health workers causes them to flee to wealthier countries, which are actively recruiting them: $40 \%$ of college-educated people in much of Africa emigrate to rich Englishspeaking. This means that two-thirds of nursing posts in Malawi's public health system are vacant, Zambia has lost threequarters of its new physicians in recent years and in South Africa, 21\% of graduating doctors migrate. ${ }^{2}$

Our thievery is also costing suffering and death. A developing country without trained health workers cannot meet the Millennium Development Goals, especially for the pregnant women (half a million of whom die every year) and children under 5 whose high death rates can be reduced by cost-effective, low

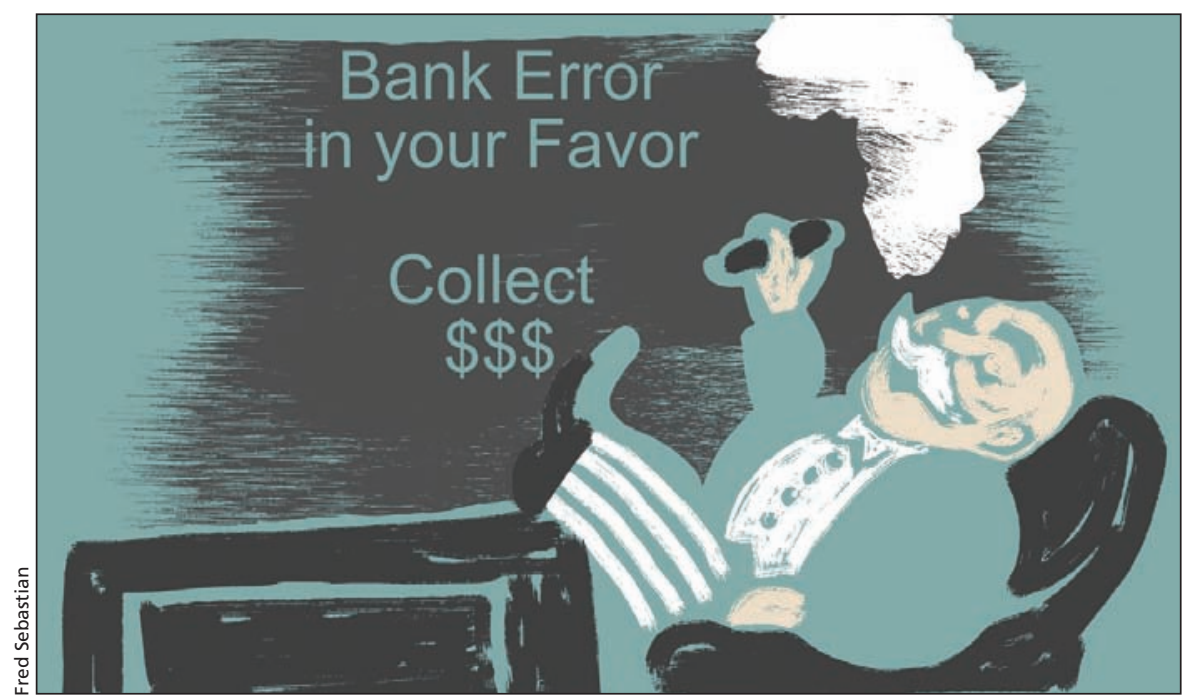

technology basic prevention and early treatment for infections.

Less than one-tenth of the money needed for maternal and neonatal health has been raised. ${ }^{3}$ The rich world is worried about sluggish economic growth and putting several percentage points of the gross domestic product toward an economic bail out. By contrast, in the poorest countries, the economies of the bottom billion ${ }^{4}$ never grow beyond $1 \%$ or $2 \%$ per year and several have negative growth. Why are we unwilling to put $0.7 \%$ of gross national product toward development? Why is it so hard to put the last first? If most developed countries now cut foreign-aid spending, who will fill the gap?

Many poor countries have started to reduce child mortality rates. In 2004, Bangladesh showed an additional 20\% decline in child mortality (it has been falling steadily), although less than $10 \%$ of women had a supervised birth. In Tanzania, the infant mortality rate fell from $100 / 1000$ live births to $68 / 1000$, but there had been no improvement in maternal mortality, antenatal care, supervised delivery or emergency obstetric care access and significant financial barriers to care. ${ }^{5}$ Ghana is on its way to middle-income status, but there is little progress in reducing maternal deaths in the poorest parts of the country, and the gap between rich and poor is widening. All of these countries have had difficulty getting the funding and human resources necessary to build sustainable health systems.

We are the chief thieves. We must discard this role and work to ensure that global aid does not fall off the agenda. We have made our commitment to the Millennium Development Goals and now is not the time to forget the bottom billion.

\section{Gretchen Roedde MD}

Family physician

International reproductive health care consultant

Temiskaming Shores, Ont.

For 20 years, Dr. Roedde has worked in more than 25 countries to reduce HIV and maternal and child mortality.

\section{REFERENCES}

1. United Nations. Trade and Development Report 2008. Geneva: United Nations; 2008.

2. Rosenberg T. Reverse Foreign Aid. The Times Magazine 2007; Mar.25.

3. UK Parliamentary Enquiry on Maternal Health Reverse Foreign Aid. 16 Oct. 2007.

4. Collier P. The bottom billion, why the poorest countries are failing and what can be done about it? New York (NY): Oxford University Press US; 2007.

5. Tanzania National Bureau of Statistics. ORC Macro. Tanzania demographic and health survey 2004-2005. Atlanta (GA): ORC Macro; 2005

Have you got an opinion about this article? Post your views at www.cmaj.ca. Potential Salon contributors are welcome to send a query to salon@cmaj.ca.

All editorial matter in CMAJ represents the opinions of the authors and not necessarily those of the Canadian Medical Association. 